\title{
Pensononowoor
}

2021, vol. 86, 29-38

https://doi.org/10.12657/denbio.086.004

\author{
Deniz Güney, Seyyed Hossein Chavoshi, Ali Bayraktar*, \\ Fahrettin Atar
}

\section{The effects of temperature and exogenous auxin on cutting propagation of some junipers}

Received: 4 April 2021; Accepted: 30 August 2021

\begin{abstract}
From past to the present, cultural, medicinal, landscape and culinary use of junipers has contributed to it being one of the most widely distributed woody plants in the world. Therefore, it is so important that finding appropriate production methods to obtain quality seedlings in line with the usage area. In the present study, it was tried to determine the best conditions and applications on propagation by cuttings of three juniper taxa including Juniperus communis L. 'Hibernica', Juniperus chinensis L. 'Stricta', and Juniperus chinensis L. 'Stricta Variegata'. For this purpose, two different greenhouse treatments (Greenhouse-1 with the air temperature at $20 \pm 2^{\circ} \mathrm{C}$, rooting table temperature at $25 \pm 2^{\circ} \mathrm{C}$ and humidity level at $70 \pm 2 \%$; Greenhouse- 2 with the air temperature at $20 \pm 2^{\circ} \mathrm{C}$, rooting table temperature at $20 \pm 2^{\circ} \mathrm{C}$ and humidity level at $70 \pm 2 \%$ ) and different auxin applications (Indole-3-Butyric Acid, Indole-3-Acetic Acid and $\alpha$-Naphthalene Acetic Acid at concentrations of 3000 and $5000 \mathrm{ppm}$ ) were designed. The highest rooting percentages were generally achieved in Greenhouse-1. IAA 5000 ppm treatment for J. communis 'Hibernica' (93.33\%) and J. chinensis 'Stricta' (66.67\%, also in Greenhouse-2) and IBA 3000 ppm treatment for J. chinensis 'Stricta Variegata' $(60.00 \%)$ showed the best rooting results. This study, in which the best production conditions are investigated in some juniper taxa, is a guiding feature for the producers to ensure the sustainable utilization of junipers.
\end{abstract}

Keywords: Ornamental plant, cutting propagation, greenhouse conditions, quality seedling

Addresses: D. Güney, A. Bayraktar, F. Atar, Department of Forest Engineering, Faculty of Forestry, Karadeniz Technical University, Trabzon, Turkey; e-mails: d_guney@ktu.edu.tr, alibayraktar@ktu.edu.tr, fatar@ktu.edu.tr; (1) DG https://orcid.org/0000-0001-7222-6162,

(1) AB https://orcid.org/0000-0002-8420-7089, (1) FA https://orcid.org/0000-0003-4594-8148

S. H. Chavoshi, Jame Iran Consulting Engineers Company, Tehran, Iran;

e-mail: chavoshi.s.hossein@gmail.com; (1) SHC https://orcid.org/0000-0002-2754-4070

*Corresponding author

\section{Introduction}

Juniperus communis L. and Juniperus chinensis L., belonging to the family Cupressaceae, are among the most widely distributed gymnosperms throughout the warm temperate and temperate climate zones in the Northern Hemisphere (Polunin \& Walters,
1985; Jalas \& Suominen, 1988; IUCN, 1998; Farjon, 2008; Lim, 2012). Since Junipers can even grow under unproductive soil conditions, they are among the valuable tree species (Gültekin et al., 2003). They can also use as an ornamental plants used in urban landscapes or used as a median trees (Tektas et al., 2017). Juniper species are rich in essential 
oils, tannins, flavonoids, resins, lignans, and triterpene (Hegnauer, 1986), produce many metabolites which constitute an important source of many pharmaceutical drugs (Al-Snafi, 2015, 2017). Species of this genus are also well-known in traditional medicine in many countries in Europe and the world, needles and particularly cones are widely used as folk remedies for digestive and gynecological disorders, cold, and headache, and are known as potent diuretic agents. It also is known that they are especially helpful against respiratory diseases, cough, bronchitis, and asthma (Leporatti \& Ivancheva, 2003; Tümen \& Hafizoğlu, 2003). There are many studies about antioxidant, anti-inflammatory, and antimicrobial activities of different Juniperus species (Glišić et al., 2007; Asili et al., 2008; Orhan et al., 2011; Taviano et al., 2011; Carpenter et al., 2012; Lesjak et al., 2013). Additionally, it was determined that nephroprotective and hepatoprotective effects of juniper leaves extract (Al-Attar et al., 2016, 2017) and cytotoxic effects of some Juniperus species in different cancer cell lines, including lung cancer A549 cells (Barrero et al., 2004; Yaglioglu \& Eser, 2017). J. communis contains monoterpenes, sesquiterpenes, essential and volatile oils, a wide range of phenolic compounds, and many other chemical compounds. It exerted many pharmacological effects such as antimicrobial, antifertility, antioxidant, cytotoxic, hepatoprotective, antidiabetic, antihyperlipidemic, anti-inflammatory, analgesic, diuretic, anti-Parkinsonian, memory enhancing, tyrosinase suppressive activity, and so on (Al-Snafi, 2018). On the other hand, because the extract of $J$. chinensis contains -piene, limonene, cedorol, widdrol, and cedrene, the species is considered as an important plant resource with a high potential value in developing new anticancer drugs or drugs against various diseases (Jo, 2012; Adams, 2014). Because of all these effects, the propagation of junipers and ensuring the continuity of quality individuals are of high importance.

Plants have considerable plasticity and adaptability that makes it possible for them to form new organs such as lateral roots, shoots, and flowers including meristems (Benková et al., 2003). Although vegetative propagation methods have naturally occurring substances that can stimulate and produce necessary phytohormones for root and shoot formation, most cuttings require additional stimulation (Carlson, 1950; Altman \& Waisel, 1997). In some studies on J. communis, various auxin concentrations were tried in cutting propagation and it was stated that auxin applications were effective on properties such as survival percentage and the number of roots (Al-Kinany, 1981; Houle \& Babeux, 1994). According to Randhawa and Mukhapadhaya (2000), cutting or layering is the best method of propagation for $J$. chinensis. The rooting capacity of stem cuttings is affected by plant species, maturity, time of year, and other factors (Esau, 1977). Arteca (1996) stated that the finding that auxins could stimulate adventitious rooting in cuttings was a breakthrough for commercial plant propagation. In commercial plant propagation, auxins are commonly used for many purposes such as increasing overall rooting percentages, hastening root initiation, increasing the number and quality of roots and encouraging uniformity of rooting (Macdonald, 1987; Hartmann et al., 2002). Over the past 70 years, three the most common methods related to applying auxin to stem cuttings have been the basal quick-dip (concentrated-solution dip or, simply, quick-dip) method, the powder (talc or dust) application method, and the dilute soak (dilute-solution soaking) method. The basal quick-dip and powder application methods tend to be most common, with the quick-dip generally considered to be the superior method of the two (Dirr \& Heuser, 1987). There are various advantages of powders: 1 ) ease of application, 2) preparation is not required with commercial formulations, 3 ) easy storage, and 4) visible evidence of application for workers (Macdonald, 1987; Blazich, 1988; Hartmann et al., 2002). In cutting propagation, perlite is a key component of most commercial substrates. Growers mostly use perlite as rooting substrates because of its aerating characteristics (Moore, 1987). Although junipers can be propagated by seeds because the germination obstacle is exceeded, high empty and rotten seed ratios and a slow development process entail the use of vegetative production techniques (Tektas et al., 2017). J. communis and J. chinensis species are used as ornamental plants as well as having many uses and benefits. This reveals the necessity of producing these species and their cultivars. This study aimed to determine the effects of different concentrations of IBA, IAA, NAA, and different rooting table temperatures on Juniperus communis 'Hibernica', Juniperus chinensis 'Stricta', and Juniperus chinensis 'Stricta Variegata' cuttings to discover the optimum auxin treatment and greenhouse condition for propagation.

\section{Methods}

The present study was conducted in The Research and Application Greenhouse at Faculty of Forestry, belonging to Karadeniz Technical University (KTU) in Trabzon/Turkey. Hardwood cuttings obtained in March 2015 for Juniperus communis 'Hibernica', Juniperus chinensis 'Stricta' and Juniperus chinensis 'Stricta Variegata' from the last annual shoots of 20-aged individuals located in KTU Kanuni Campus were investigated as study material (Fig. 1). To be used in the study, Greenhouse-1 treatment (air temperature at $20 \pm 2^{\circ} \mathrm{C}$, rooting table temperature at $25 \pm 2^{\circ} \mathrm{C}$ 
and air humidity level at $70 \pm 2 \%$ ) and Greenhouse-2 treatment (air temperature at $20 \pm 2^{\circ} \mathrm{C}$, rooting table temperature at $20 \pm 2^{\circ} \mathrm{C}$, and air humidity level at $70 \pm 2 \%$ ) with technological systems were adjusted by the automation system regulating fogging, misting, irrigation and temperature settings. Due to high water retention and aeration capacity, perlite was used as a rooting medium in both greenhouses.
The powder form of IBA (Indole-3-Butyric Acid), IAA (Indole-3-Acetic Acid), and NAA ( $\alpha$-Naphthalene Acetic Acid) of 3000 and 5000 ppm concentrations were selected to induce rooting from the auxin group plant growth regulators. The study was set up to be three repetitions, according to the 'randomized complete block design'. A total of 1260 cuttings were planted to rooting including 3 taxa $\times 3$ auxins $\times 2$

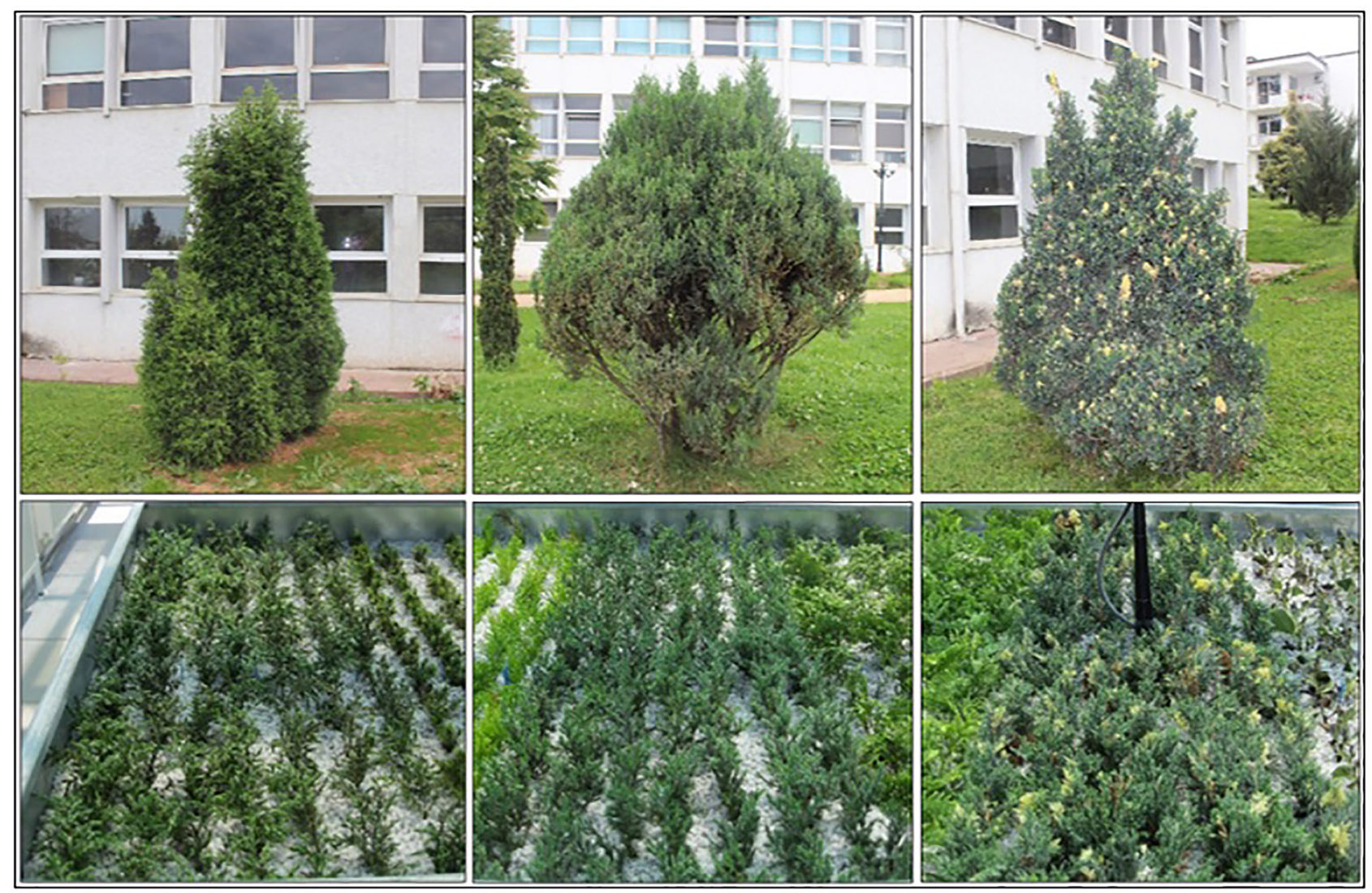

Fig. 1. General habitus of stock plants and status of planted cuttings (J. communis 'Hibernica', J. chinensis 'Stricta', J. chinensis 'Stricta Variegata'; from left to right, respectively)
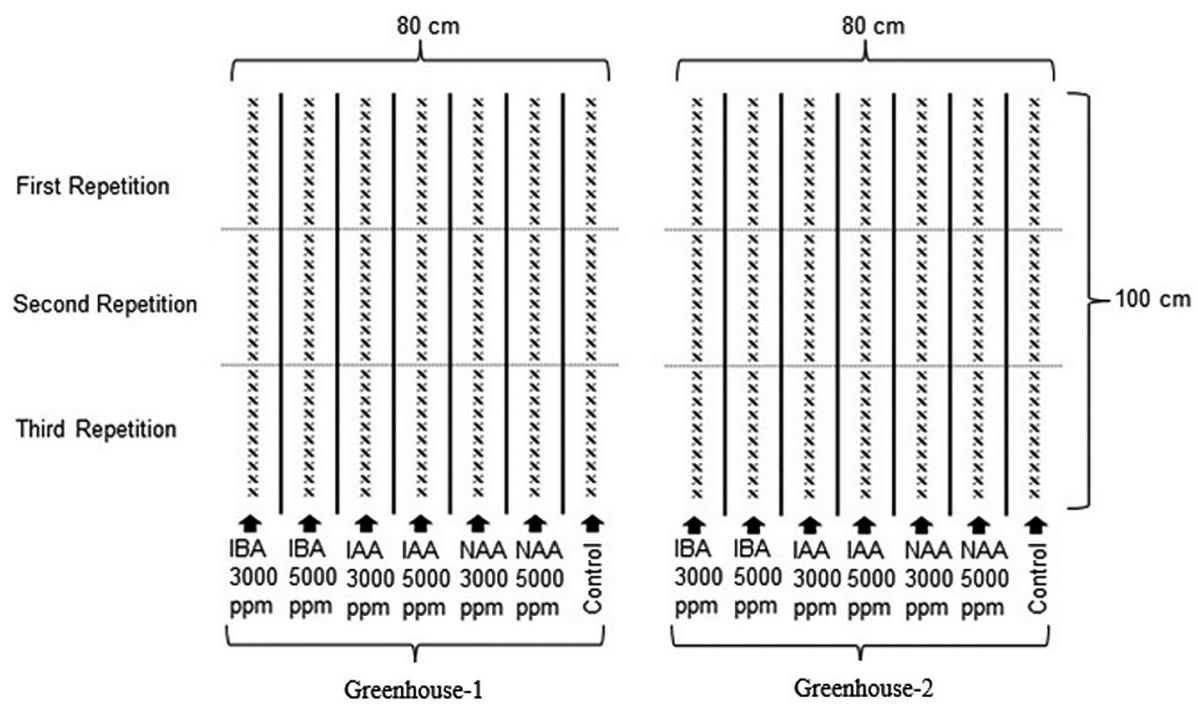

Fig. 2. Trial design related to planted cuttings in greenhouse 
concentrations $\times 2$ greenhouses $\times 1$ rooting medium $\times 10$ cuttings $\times 3$ repetitions (1080 cuttings) and control (untreated) cuttings for each taxon in both greenhouses (180 cuttings: 3 taxa $\times 2$ greenhouses $\times 1$ rooting medium $\times 10$ cuttings $\times 3$ repetitions). Cuttings taken from the determined stock plant early in the morning were generally prepared to be $10-12 \mathrm{~cm}$ long and planted in the rooting medium. The schematic representation of the trial design used for planted cuttings in each greenhouse medium is given in Fig. 2.

The prepared cuttings of J. communis 'Hibernica', J. chinensis 'Stricta' and J. chinensis 'Stricta Variegata' were planted on 15 March 2014. Cuttings were traced from the time they were transferred in the rooting medium. The cuttings were inspected every three days. The determined cuttings for each treatment were removed from the rooting medium and their callus and root formation conditions were determined. This process was carried out very meticulously in order not to damage the cuttings removed from the rooting medium. In the measurements made in removed cuttings after the root formation was completed, the first callus and first root formation dates, rooting percentage $(\mathrm{RP})$, callus percentage $(\mathrm{CP})$, root length $(\mathrm{RL})$, and the number of roots ( $R N)$ values were determined. The data were analyzed using SPSS 23 statistical program. Analysis of variance (univariate) was conducted to determine the effects of different greenhouse (G) and auxin (A) treatments on rooting percentage, callus percentage, root length, and the number of roots. In addition, Duncan's test was performed to determine the groups that were found in terms of auxins and greenhouses for RP, CP, RL and RN.

\section{Results}

Juniperus communis 'Hibernica' cuttings at the end of 135 days, Juniperus chinensis 'Stricta' cuttings at the end of 226 days, and Juniperus chinensis 'Stricta Variegata' cuttings at the end of 163 days were removed from rooting medium. The first root formation (after 38 days from planting) of $J$. communis 'Hibernica' occurred in NAA 3000 ppm treatment in Greenhouse-2. For J. chinensis 'Stricta', the first callus (after 58 days from planting) and root (after 128 days from planting) formations were determined in IBA 3000 ppm treatment in Greenhouse-2. The first callus formation of $J$. chinensis 'Stricta Variegata' took place in IBA 3000 ppm treatment in Greenhouse-1 at the end of 42 days. Moreover, the first root formation appeared in NAA 5000 ppm treatment in Greenhouse-2 at the end of 81 days. Depending on the effects of the different greenhouses and auxins on the rooted cuttings of all studied taxa, rooting percentage, callus percentage, root length, and the number of roots are given in Table 1 . As a result of analysis of variance (univariate), RP and CP are expressed as mean, while RL and $\mathrm{RN}$ are expressed as mean \pm standard deviation.

The values of higher rooting percentage were generally obtained in Greenhouse-1 for all studied taxa (Table 1). In terms of rooting percentage, while IAA 5000 ppm was the most effective treatment with the highest percentage for J. communis ' $\mathrm{Hi}$ bernica' (93.33\%) and J. chinensis 'Stricta' (66.67\%, also in Greenhouse-2), IBA 3000 ppm treatment was the best treatment for J. chinensis 'Stricta Variegata' $(60.00 \%)$. For J. communis 'Hibernica', callus formation did not occur. However, the highest callus percentage was determined as $73.33 \%$ in IAA 3000 ppm treatment in Greenhouse-1 for J. chinensis 'Stricta', and it was determined as $16.67 \%$ in control cuttings in also Greenhouse-1 for J. chinensis 'Stricta Variegata'. When the data on the root length were examined, on the one hand, Greenhouse- 1 had the longest root length for J. communis 'Hibernica' (as $9.86 \mathrm{~cm}$ in IBA 5000 ppm treatment) and J. chinensis 'Stricta' (as $23.28 \mathrm{~cm}$ in IAA $3000 \mathrm{ppm}$ treatment). On the other hand, Greenhouse-2 had the longest root length for J. chinensis 'Stricta Variegata' (as $26.08 \mathrm{~cm}$ in IAA $3000 \mathrm{ppm}$ treatment). The highest number of roots belonging to J. communis 'Hibernica' occurred as 8.17 roots in IBA 3000 ppm treatment in Greenhouse-2. Although the highest number of roots for J. chinensis 'Stricta' was determined in control cuttings (3.71 roots) in Greenhouse-2, the next highest value was in IBA 3000 ppm treatment (3.39 roots) in Greenhouse-1. The highest number of roots for J. chinensis 'Stricta Variegata' was determined as 2.67 roots in IBA 5000 ppm treatment in Greenhouse-2 (Table 2).

For all studied taxa, differences among greenhouse treatment, auxin treatment, and their interaction were statistically significant $(p<0.05)$ in terms of rooting percentage. According to the ANOVA results, the only statistically significant difference $(p<0.05)$ related to callus percentage occurred in greenhouse treatment for J. chinensis 'Stricta'. For J. communis 'Hibernica', statistically significant differences $(p<0.05)$ emerged in auxin treatment and greenhouse $\times$ auxin interaction in terms of root length, and in greenhouse treatment in terms of the number of roots. There was no statistically significant difference for J. chinensis 'Stricta Variegata' in terms of root length and the number of roots, whereas in J. chinensis 'Stricta' there was a statistically significant difference $(p<0.05)$ in greenhouse treatment for root length. In terms of greenhouse $\times$ auxin interaction, the statistically significant differences were in rooting percentages of all studied taxa and root length of J. communis 'Hibernica'. Thus, the graphical representation of the values having statistically significant differences are given in Fig. 3, and Duncan's test results are given in Table 3 in terms of auxins. 
For J. communis 'Hibernica', high results in terms of rooting percentage and root length were yielded in Greenhouse-1. But, IAA 3000 ppm and NAA $5000 \mathrm{ppm}$ treatments and control cuttings in terms of root length were more effective in Greenhouse-2.
Although an increase occurred in Greenhouse-2 in terms of the rooting percentages of the IAA 3000 ppm, NAA 3000 ppm treatments, and control cuttings for J. chinensis 'Stricta', the highest results were again in Greenhouse-1. The same was true once for

Table 1. The results of measured characteristics depend on auxin and greenhouse treatments

\begin{tabular}{|c|c|c|c|c|c|c|}
\hline Taxon & $\mathrm{G}$ & $\mathrm{A}$ & $\mathrm{RP}(\%)$ & CP (\%) & $\mathrm{RL}(\mathrm{cm})$ & RN (roots) \\
\hline \multirow{16}{*}{$\begin{array}{l}\text { Juniperus communis } \\
\text { 'Hibernica' }\end{array}$} & \multirow[t]{8}{*}{ Greenhouse-1 } & IBA 3000 ppm & 73.33 & 0.00 & $8.38 \pm 3.62$ & $4.86 \pm 3.31$ \\
\hline & & IBA 5000 ppm & 90.00 & 0.00 & $9.86 \pm 3.69$ & $4.37 \pm 2.34$ \\
\hline & & IAA 3000 ppm & 76.67 & 0.00 & $6.58 \pm 3.01$ & $4.30 \pm 2.77$ \\
\hline & & IAA 5000 ppm & 93.33 & 0.00 & $7.66 \pm 3.01$ & $3.68 \pm 1.81$ \\
\hline & & NAA 3000 ppm & 60.00 & 0.00 & $6.12 \pm 3.15$ & $4.28 \pm 2.30$ \\
\hline & & NAA 5000 ppm & 86.67 & 0.00 & $6.08 \pm 2.57$ & $5.19 \pm 2.79$ \\
\hline & & Control & 60.00 & 0.00 & $5.57 \pm 3.39$ & $3.78 \pm 2.44$ \\
\hline & & Average & 77.14 & 0.00 & $7.31 \pm 3.47$ & $4.36 \pm 2.56$ \\
\hline & \multirow[t]{8}{*}{ Greenhouse-2 } & IBA 3000 ppm & 60.00 & 0.00 & $8.10 \pm 2.92$ & $8.17 \pm 4.22$ \\
\hline & & IBA 5000 ppm & 80.00 & 0.00 & $7.77 \pm 2.46$ & $5.54 \pm 3.58$ \\
\hline & & IAA 3000 ppm & 63.33 & 0.00 & $8.21 \pm 2.06$ & $7.79 \pm 3.58$ \\
\hline & & IAA 5000 ppm & 76.67 & 0.00 & $7.07 \pm 3.37$ & $6.22 \pm 3.49$ \\
\hline & & NAA 3000 ppm & 33.33 & 0.00 & $5.78 \pm 2.68$ & $5.50 \pm 2.46$ \\
\hline & & NAA 5000 ppm & 50.00 & 0.00 & $6.50 \pm 3.28$ & $7.20 \pm 4.44$ \\
\hline & & Control & 53.33 & 0.00 & $7.56 \pm 2.79$ & $7.69 \pm 4.91$ \\
\hline & & Average & 59.52 & 0.00 & $7.42 \pm 2.85$ & $6.86 \pm 3.93$ \\
\hline \multirow{16}{*}{$\begin{array}{l}\text { Juniperus chinensis } \\
\text { 'Stricta' }\end{array}$} & \multirow[t]{8}{*}{ Greenhouse-1 } & IBA 3000 ppm & 60.00 & 36.67 & $16.54 \pm 4.98$ & $3.39 \pm 2.28$ \\
\hline & & IBA 5000 ppm & 60.00 & 33.33 & $18.24 \pm 8.04$ & $2.39 \pm 1.42$ \\
\hline & & IAA 3000 ppm & 26.67 & 73.33 & $23.28 \pm 9.64$ & $2.38 \pm 1.30$ \\
\hline & & IAA 5000 ppm & 66.67 & 33.33 & $22.89 \pm 9.16$ & $2.55 \pm 1.32$ \\
\hline & & NAA 3000 ppm & 26.67 & 53.33 & $19.39 \pm 5.27$ & $1.75 \pm 0.71$ \\
\hline & & NAA 5000 ppm & 56.67 & 40.00 & $20.87 \pm 9.89$ & $2.59 \pm 1.33$ \\
\hline & & Control & 36.67 & 63.33 & $17.04 \pm 6.77$ & $1.91 \pm 1.30$ \\
\hline & & Average & 47.62 & 47.62 & $19.68 \pm 8.17$ & $2.53 \pm 1.55$ \\
\hline & \multirow[t]{8}{*}{ Greenhouse-2 } & IBA 3000 ppm & 40.00 & 13.33 & $15.75 \pm 5.42$ & $1.67 \pm 0.89$ \\
\hline & & IBA 5000 ppm & 50.00 & 16.67 & $14.05 \pm 7.35$ & $2.93 \pm 3.22$ \\
\hline & & IAA 3000 ppm & 53.33 & 10.00 & $12.96 \pm 5.54$ & $2.25 \pm 1.29$ \\
\hline & & IAA 5000 ppm & 66.67 & 13.33 & $14.87 \pm 7.76$ & $2.40 \pm 1.31$ \\
\hline & & NAA 3000 ppm & 56.67 & 20.00 & $11.17 \pm 5.74$ & $2.12 \pm 1.11$ \\
\hline & & NAA 5000 ppm & 36.67 & 10.00 & $13.75 \pm 4.24$ & $2.82 \pm 2.14$ \\
\hline & & Control & 46.67 & 20.00 & $9.93 \pm 5.59$ & $3.71 \pm 2.84$ \\
\hline & & Average & 50.00 & 14.76 & $13.18 \pm 6.33$ & $2.54 \pm 2.00$ \\
\hline \multirow{16}{*}{$\begin{array}{l}\text { Juniperus chinensis } \\
\text { 'Stricta Variegata' }\end{array}$} & \multirow[t]{8}{*}{ Greenhouse-1 } & IBA 3000 ppm & 60.00 & 3.33 & $14.69 \pm 9.41$ & $1.72 \pm 1.07$ \\
\hline & & IBA 5000 ppm & 26.67 & 10.00 & $11.44 \pm 11.08$ & $1.63 \pm 1.19$ \\
\hline & & IAA 3000 ppm & 3.33 & 0.00 & $8.50 \pm 0.00$ & $1.00 \pm 0.00$ \\
\hline & & IAA 5000 ppm & 23.33 & 0.00 & $13.08 \pm 8.60$ & $2.00 \pm 1.15$ \\
\hline & & NAA 3000 ppm & 26.67 & 0.00 & $17.33 \pm 5.65$ & $1.75 \pm 0.71$ \\
\hline & & NAA 5000 ppm & 43.33 & 6.67 & $15.83 \pm 9.54$ & $1.77 \pm 0.93$ \\
\hline & & Control & 23.33 & 16.67 & $19.44 \pm 8.46$ & $1.57 \pm 0.98$ \\
\hline & & Average & 29.52 & 5.24 & $15.10 \pm 8.98$ & $1.73 \pm 0.98$ \\
\hline & \multirow[t]{8}{*}{ Greenhouse-2 } & IBA 3000 ppm & 30.00 & 6.67 & $11.70 \pm 9.99$ & $1.44 \pm 0.53$ \\
\hline & & IBA 5000 ppm & 10.00 & 3.33 & $6.82 \pm 4.34$ & $2.67 \pm 2.08$ \\
\hline & & IAA 3000 ppm & 6.67 & 0.00 & $26.08 \pm 8.24$ & $1.00 \pm 0.00$ \\
\hline & & IAA 5000 ppm & 3.33 & 0.00 & $7.10 \pm 0.00$ & $1.00 \pm 0.00$ \\
\hline & & NAA 3000 ppm & 20.00 & 0.00 & $15.96 \pm 13.31$ & $2.17 \pm 1.17$ \\
\hline & & NAA 5000 ppm & 23.33 & 0.00 & $14.33 \pm 11.15$ & $1.14 \pm 0.38$ \\
\hline & & Control & 16.67 & 0.00 & $11.97 \pm 9.75$ & $1.80 \pm 0.84$ \\
\hline & & Average & 15.71 & 1.43 & $13.36 \pm 10.44$ & $1.64 \pm 0.96$ \\
\hline
\end{tabular}

G - Greenhouse treatment; A - Auxin treatment; RP - mean rooting percentage; CP - mean callus percentage; RL - mean root length $( \pm S D)$; RN - mean number of roots $( \pm S D)$. 
J. chinensis 'Stricta Variegata' and Greenhouse-1 had the highest results.

Different letters represent groupings related to auxin treatments for RP and RL in all studied taxa according to Duncan's test.

When Duncan's test results for auxins were evaluated, six different groups occurred in terms of RP for J. communis 'Hibernica' (Table 3). While IBA and IAA 5000 ppm treatments with $85.00 \%$ formed the first group, NAA 3000 ppm treatment with $46.67 \%$ created the last group. In addition, four different groups were determined for RL values belonging to J. communis 'Hibernica'. According to this, the first
Table 3. Groups distinguished as a result of Duncan's test related to auxin treatments

\begin{tabular}{|c|c|c|c|c|}
\hline & \multicolumn{2}{|c|}{$\begin{array}{l}\text { J. communis } \\
\text { 'Hibernica' }\end{array}$} & \multirow{2}{*}{$\begin{array}{l}\text { J. chinensis } \\
\text { 'Stricta' } \\
\text { RP (\%) } \\
\end{array}$} & \multirow{2}{*}{$\begin{array}{c}\text { J. chinensis } \\
\text { 'Stricta Variegata' } \\
\text { RP (\%) } \\
\end{array}$} \\
\hline & $\mathrm{RP}(\%)$ & $\mathrm{RL}(\mathrm{cm})$ & & \\
\hline IBA 3000 ppm & $66.67 c$ & $8.25 \mathrm{ab}$ & $50.00 \mathrm{c}$ & $45.00 \mathrm{a}$ \\
\hline IBA 5000 ppm & $85.00 \mathrm{a}$ & $8.88 \mathrm{a}$ & $55.00 \mathrm{~b}$ & $18.34 \mathrm{~d}$ \\
\hline IAA 3000 ppm & $70.00 \mathrm{~b}$ & $7.32 \mathrm{bc}$ & $40.00 \mathrm{e}$ & $5.00 \mathrm{f}$ \\
\hline IAA 5000 ppm & $85.00 \mathrm{a}$ & 7.40 bc & $66.67 \mathrm{a}$ & $13.33 \mathrm{e}$ \\
\hline NAA 3000 ppm & $46.67 \mathrm{e}$ & $6.00 \mathrm{c}$ & $41.67 \mathrm{e}$ & $23.34 \mathrm{c}$ \\
\hline NAA 5000 ppm & $68.34 b c$ & $6.23 c$ & $46.67 \mathrm{~d}$ & $33.33 \mathrm{~b}$ \\
\hline Control & $56.67 \mathrm{~d}$ & $6.51 \mathrm{c}$ & $41.67 \mathrm{e}$ & $20.00 \mathrm{~d}$ \\
\hline
\end{tabular}

$\mathrm{RP}$ - rooting percentage; $\mathrm{RL}$ - root length.

Table 2. Analysis of variance (univariate) on measured characteristics

\begin{tabular}{|c|c|c|c|c|c|c|c|c|c|}
\hline & & \multicolumn{2}{|c|}{$\mathrm{RP}$} & \multicolumn{2}{|c|}{$\mathrm{CP}$} & \multicolumn{2}{|c|}{$\mathrm{RL}$} & \multicolumn{2}{|c|}{$\mathrm{RN}$} \\
\hline & & $\mathrm{F}$ & $p$ & $\mathrm{~F}$ & $p$ & $\mathrm{~F}$ & $p$ & $\mathrm{~F}$ & $p$ \\
\hline \multirow[t]{3}{*}{1} & $G$ & 814.969 & $0.000^{*}$ & - & - & 0.080 & 0.778 & 41.301 & $0.000^{*}$ \\
\hline & A & 291.696 & $0.000^{*}$ & - & - & 4.545 & $0.000^{*}$ & 1.804 & 0.098 \\
\hline & $\mathrm{G} \times \mathrm{A}$ & 41.276 & $0.000^{*}$ & - & - & 2.223 & $0.041^{*}$ & 1.113 & 0.355 \\
\hline \multirow[t]{3}{*}{2} & G & 14.869 & $0.001^{*}$ & 56.679 & $0.000^{*}$ & 39.215 & $0.000^{*}$ & 0.276 & 0.600 \\
\hline & A & 135.717 & $0.000^{*}$ & 2.131 & 0.081 & 1.824 & 0.096 & 0.645 & 0.694 \\
\hline & $\mathrm{G} \times \mathrm{A}$ & 160.694 & $0.000^{*}$ & 1.956 & 0.106 & 1.298 & 0.260 & 2.388 & 0.030 \\
\hline \multirow[t]{3}{*}{3} & G & 500.526 & $0.000^{*}$ & 3.200 & 0.084 & 0.106 & 0.745 & 0.012 & 0.914 \\
\hline & A & 259.518 & $0.000^{*}$ & 1.517 & 0.209 & 0.822 & 0.556 & 0.935 & 0.474 \\
\hline & $G \times A$ & 46.447 & $0.000^{*}$ & 1.450 & 0.231 & 0.671 & 0.673 & 1.066 & 0.390 \\
\hline
\end{tabular}

1 - Juniperus communis 'Hibernica'; 2 - Juniperus chinensis 'Stricta'; 3 - Juniperus chinensis 'Stricta Variegata'.

G - Greenhouse treatment; A - Auxin treatment; RP - rooting percentage; CP - callus percentage; RL - root length; RN - the number of roots.

${ }^{*} p<0.05$ (there is a statistically significant difference).
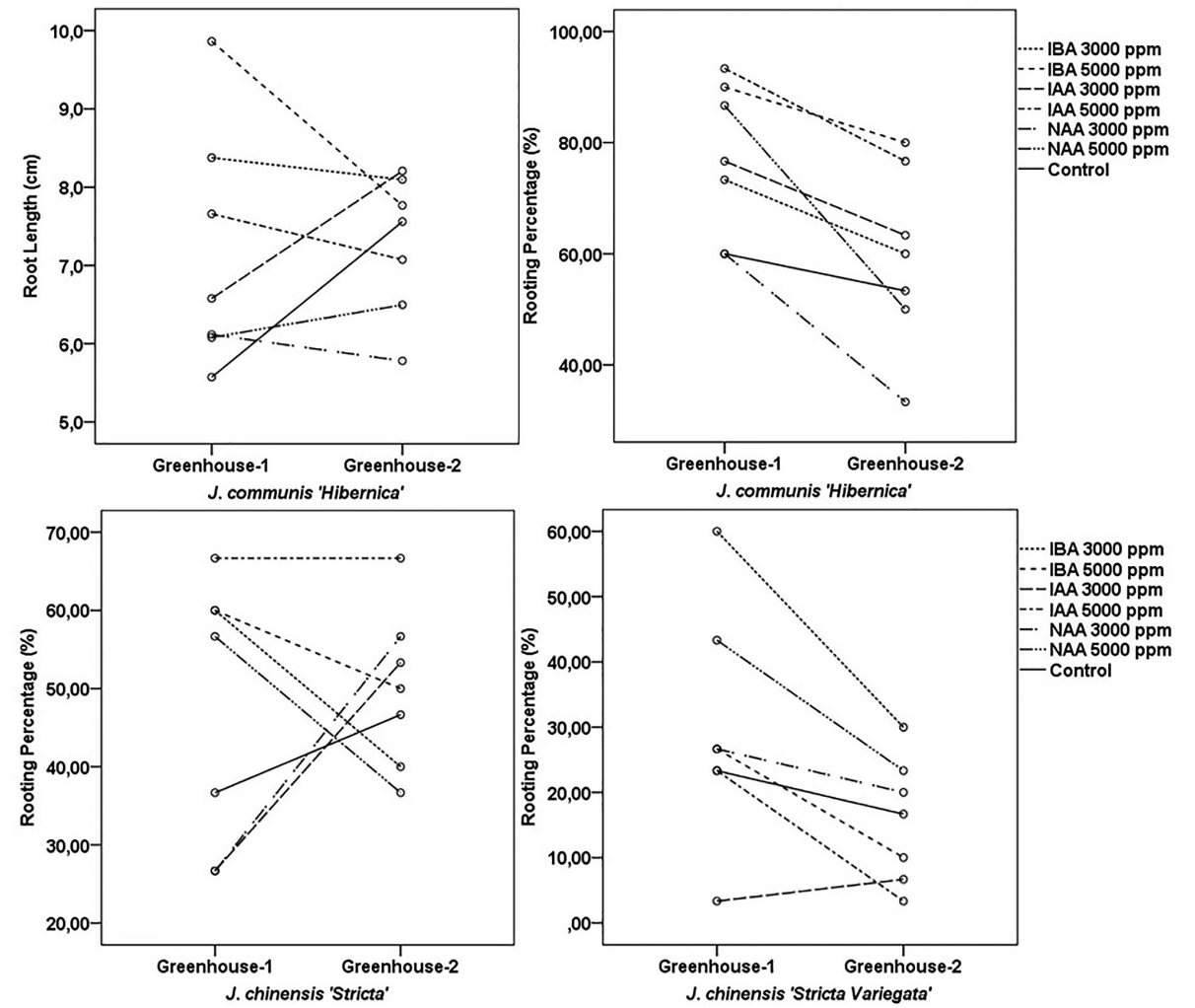

Fig. 3. The influence of auxin and greenhouse treatments on root length and rooting percentage 
group was formed by IBA 5000 ppm treatment $(8.88$ $\mathrm{cm})$, and the last group was created by NAA 3000 ppm $(6.00 \mathrm{~cm})$, NAA $5000 \mathrm{ppm}(6.23 \mathrm{~cm})$ treatments, and control cuttings $(6.51 \mathrm{~cm})$. It was determined that there were five different groups in terms of RP for $J$. chinensis 'Stricta'. Whereas the highest result with $66.67 \%$ was revealed by IAA 5000 ppm treatment, the lowest results were taken place by IAA 3000 ppm (40.00\%), NAA 3000 ppm (41.67\%) treatments and control cuttings $(41.67 \%)$. In terms of RP for J. chinensis 'Stricta Variegata', six different groups arose. IBA $3000 \mathrm{ppm}$ treatment produced the highest results with $45.00 \%$ and IAA $3000 \mathrm{ppm}$ treatment produced the lowest results with $5.00 \%$.

\section{Discussion}

While the highest rooting percentages for all studied taxa occurred in Greenhouse-1 (air temperature at $20 \pm 2^{\circ} \mathrm{C}$, rooting table temperature at $25 \pm 2^{\circ} \mathrm{C}$, and air humidity level at $70 \pm 2 \%$ ), Greenhouse- 2 produced less effective results (air temperature at $20 \pm 2^{\circ} \mathrm{C}$, rooting table temperature at $20 \pm 2^{\circ} \mathrm{C}$ and air humidity level at $70 \pm 2 \%$ ). Cuttings treated by IAA 5000 ppm for Juniperus communis 'Hibernica' had the highest rooting percentage with $93.33 \%$; while the longest root length was obtained as 9.86 $\mathrm{cm}$ in IBA $5000 \mathrm{ppm}$ treatment in Greenhouse-1, and the highest number of roots was determined as 8.17 roots in IBA 3000 ppm treatment in Greenhouse-2. Al-Kinany (1981) reported that Juniperus communis cuttings treated by IBA 4000 ppm showed encouraging results in survival percentage. Moreover, higher concentrations than this should be tried to enhance the survival percentage of rooted cuttings still further. In another study related to variations in rooting ability of cuttings of Juniperus communis var. depressa, Houle \& Babeux (1994) reported that a higher proportion of cuttings from female shrubs rooted than from male shrubs. Juniperus communis var. depressa cuttings treated with $8 \mathrm{gL}^{-1}$ of IBA produced more roots than those treated with $12 \mathrm{gL}^{-1}$. Additionally, while rooting auxin concentration (IBA) had a significant effect on the number of roots initiated by cuttings, it was not effective on root length that was not significantly affected by gender or by IBA level. In the scope of this study, for Juniperus chinensis 'Stricta', the highest rooting percentage was achieved as $66.67 \%$ in IAA 5000 ppm in both Greenhouse-1 and Greenhouse-2. IAA 3000 ppm treatment in Greenhouse-1 having the highest callus percentage $(73.33 \%)$, and had the longest root length $(23.28 \mathrm{~cm})$. The highest number of roots was determined as 3.71 roots in control cuttings in Greenhouse-2, but IBA 3000 ppm treatment in Greenhouse-1 followed this with 3.39 roots. In terms of rooting percentage of Juniperus chinensis 'Stricta Variegata', IBA 3000 ppm treatment had the highest result with $60.00 \%$ in Greenhouse-1 that had also the highest callus percentage with $16.67 \%$ in control cuttings. Both the longest root length (as $26.08 \mathrm{~cm}$ in IAA $3000 \mathrm{ppm}$ treatment) and the highest number of roots (as 2.67 roots in IBA 5000 ppm treatment) were in Greenhouse-2 for Juniperus chinensis 'Stricta Variegata'. In a study made on the effect of different growth regulators on the propagation of Juniperus chinensis var. pyramidalis, the best result was obtained as $98.33 \%$ in NAA 2000 ppm treatment in cuttings taken on $1^{\text {st }}$ day of July (Chowdhuri, 2017). Song et al. (2010) reported that the optimum cutting time for Juniperus chinensis var. sargentii was from April to May in hardwood cutting, and the application of IBA $1000 \mathrm{mg} \mathrm{L}^{-1}$ (rooting rate: $36.4 \%$ ) was most effective in callus formation and rooting of cutting. In a study conducted by Cope \& Rupp (2013) on cutting propagation of Juniperus osteosper$m a$ (Torr.) Little, the highest rooting percentage was determined as $69 \%$ in IBA 8000 ppm treatment in 2:1 perlite:peat ( $v: v)$ rooting substrate with 21 bottom heat. In another study investigating the effects of rooting table temperatures on cutting propagation of Taxus baccata L., it has been reported that the rooting table temperature being 5 higher than the air temperature gives positive results on rooting success (Bayraktar et al., 2018a). There are also many studies investigating auxin effects on the vegetative propagation of junipers. Keskin (1992) on Juniperus foetidissima Willd. and Juniperus excelsa Bieb., Edson et al. (1996) on Juniperus scopulorum Sarg., Negash (2002) on Juniperus procera Hochst. ex Endl., Cope \& Rupp (2013) on Juniperus osteosperma (Torr.) Little, and Tektas et al. (2017) on Juniperus excelsa stated that auxins including IAA, IBA, and NAA promoted and increased rooting. Some other studies investigating the effects of auxin on the vegetative propagation of different coniferous (Rizi et al. (2006) on Picea glauca (Moench) Voss 'Albertiana Conica', Vakouftsis et al. (2009) on Cupressus macrocarpa Hartw. 'Goldcrest', and Bayraktar et al. (2018a) on Taxus baccata L.) and deciduous (Ion (2011) on Spiraea vanhouttei, Paradikovic et al. (2013) on Rosmarinus officinalis Spenn. 'Pyramidalis', Bayraktar et al. (2018b) on Elaeagnus umbellata Thunb., and Mukhtar (2019) on Balanites aegyptiaca (L.) Delile, and Yıldırım et al. (2020) on Salix anatolica Ziel. \& D. Tomasz.) plants have also shown that auxins increase rooting.

\section{Conclusions}

When the results obtained in the present study are taken into consideration, it is determined that Greenhouse-1 (air temperature at $20 \pm 2^{\circ} \mathrm{C}$, rooting table temperature at $25 \pm 2^{\circ} \mathrm{C}$, and air humidity level 
at $70 \pm 2 \%$ ) gives generally effective results for all studied taxa. From this point of view, it can be recommended for higher results that the temperature of the rooting table is about $5^{\circ} \mathrm{C}$ higher than the air temperature when adjusting the internal conditions of the greenhouse to obtain a high rooting percentage and morphologically qualified individuals. On the other hand, considering that $3000 \mathrm{ppm}$ and 5000 ppm doses of IAA and IBA auxins give high results in terms of overall measured morphological characteristics, the use of these auxins and dose combinations may be preferred in the vegetative propagation of these taxa. In addition, the consequences of using higher doses of these auxins are an area of research for further studies. Because junipers have cultural, medicinal, landscape and culinary uses, the production, and propagation of quality seedlings have a high importance. This study, in which the best production conditions are investigated in some juniper taxa, is a guiding feature for the producers to ensure the sustainable utilization of junipers.

\section{Acknowledgments}

This work was supported by Research Fund of the Karadeniz Technical University (Project No: 9721).

\section{References}

Adams RP (2014) Junipers of the world: The genus Juniperus. Bloomington: Trafford Publishing, Vancouver, Canada.

Al-Attar AM, Alrobai AA \& Almalki, DA (2016) Effect of Olea oleaster and Juniperus procera leaves extracts on thioacetamide induced hepatic cirrhosis in male albino mice. Saudi Journal of Biological Sciences 23: 363-371. doi: 10.1016/j. sjbs.2015.08.011.

Al-Attar AM, Alrobai AA \& Almalki DA (2017) Protective effect of olive and juniper leaves extracts on nephrotoxicity induced by thioacetamide in male mice. Saudi Journal of Biological Sciences 24: 15-22. doi: 10.1016/j.sjbs.2015.08.013.

Al-Kinany A (1981) Effect of auxins on root formation in the vegetative propagation of Populus alba, Populus tremula, Picea abies and Juniperus communis. Indian Forester 107: 537-550.

Al-Snafi AE (2015) Therapeutic properties of medicinal plants: a review of their detoxification capacity and protective effects (part 1). Asian Journal of Pharmaceutical Science and Technology 5: 257270.

Al-Snafi AE (2017) Chemical contents and medical importance of Dianthus caryophyllus- A review. IOSR Journal of Pharmacy 7: 61-71.
Al-Snafi AE (2018) Medical importance of Juniperus communis - A Review. Indo American Journal of Pharmaceutical Sciences 5: 1779-1792. doi: 10.5281/zenodo.1210529.

Altman A \& Waisel YY (1997) Biology of root formation and development. Plenum Publishing Co., New York, NY, USA.

Arteca RN (1996) Plant growth substances: Principles and applications. Chapman and Hall, New York, NY, USA.

Asili J, Emami SA, Rahimizadeh M, Fazly-Bazzaz BS \& Hassanzadeh MK (2008) Chemical and antimicrobial studies of Juniperus communis subsp. hemisphaerica and Juniperus oblonga essential oils. Journal of Essential Oil-Bearing Plants 11: 96-105. doi: 10.1080/0972060X.2008.10643604.

Barrero AF, Del Moral FQ, Herrador MM, Akssira M, Bennamara A, Akkad S \& Aitigri M (2004) Oxygenated diterpenes and other constituents from Moroccan Juniperus phoenicea and Juniperus thurifera var. africana. Phytochemistry 65: 2507-2515. doi: 10.1016/j.phytochem.2004.07.021.

Bayraktar A, Atar F, Yıldırım N \& Turna İ (2018a) Effects of different media and hormones on propagation by cuttings of European yew (Taxus baccata L.). Sumarski List 142: 509-516. doi:10.31298/ sl.142.9-10.6.

Bayraktar A, Yıldırım N, Atar F \& Turna İ (2018b) Effects of some auxins on propagation by hardwood cutting of Autumn Olive (Elaeagnus umbellata Thunb.). Turkish Journal of Forestry Research 5: 112-116. doi: 10.17568/ogmoad.401438.

Benková E, Michniewicz M, Sauer M, Teichmann T, Seifertová D, Jürgens G \& Friml J (2003) Local, efflux-dependent auxin gradients as a common module for plant organ formation. Cell 115: 591602. doi: 10.1016/s0092-8674(03)00924-3.

Blazich FA (1988) Chemicals and formulations used to promote adventitious rooting. (ed. by TE Davis, BE Haissig \& N Sankhla), Dioscorides Press, Portland, OR, USA, pp. 132-149.

Carlson MC (1950) Nodal adventitious roots in willow stems of different ages. American Journal of Botany 37: 555-567. doi: 10.2307/2438033.

Carpenter CD, O’Neill T, Picot N, Johnson JA, Robichaud GA, Webster D \& Gray CA (2012) Anti-mycobacterial natural products from the Canadian medicinal plant Juniperus communis. Journal of Ethnopharmacol 143: 695-700. doi: 10.1016/j. jep.2012.07.035.

Chowdhuri TK (2017) Performance evaluation of different growth regulators on propagation of Chinese juniper (Juniperus chinensis var. pyramidalis) in subtropical zone. Journal of Pharmacognosy and Phytochemistry 6: 2190-2193.

Cope KR \& Rupp LA (2013) Vegetative propagation of Juniperus osteosperma (Utah Juniper) by 
cuttings. Native Plants Journal 14: 76-84. doi: 10.3368/npj.14.2.76.

Dirr MA \& Heuser CW (1987) The Reference manual of woody plant propagation: From seed to tissue culture. Varsity Press Inc., Athens, GA, USA.

Edson JL, Wenny DL, Kasten Dumroese R \& Leege-Brusven A (1996) Mass propagation of Rocky Mountain juniper from shoot tip cuttings. Tree Planters Notes 47: 94-99.

Esau K (1977) Anatomy of seed plants, 2nd ed. Wiley, New York, NY, USA.

Farjon, A., 2008: The natural history of conifers. Timber Press, Portland, OR, USA.

Glišić SB, Milojević SŽ, Dimitrijević SI, Orlović AM \& Skala DU (2007) Antimicrobial activity of the essential oil and different fractions of Juniperus communis L. and a comparison with some commercial antibiotics. Journal of the Serbian Chemical Society 72: 311-320. doi: 10.2298/JSC0704311G.

Gültekin HC, Gülcü S, Gültekin ÜG \& Divrik A (2003) Studies on determination the effects of some practicable classification methods on seed germination of Crimean Juniper (Juniperus excelsa Bieb.) before sowing process. Artvin Coruh University Journal of Forestry Faculty 4: 111-120.

Hartmann HT, Kester DE, Davies FT \& Geneve RL (2002) Hartmann and Kester's plant propagation: Principles and practices, 7th ed. Prentice Hall, Upper Saddle River, NJ, USA.

Hegnauer R (1986) Chemotaxonomie der Pflanzen. Birkhauser Verlag, Basel, CH.

Houle G \& Babeux P (1994) Variations in rooting ability of cuttings and in seed characteristics of five populations of Juniperus communis var. depressa from subarctic Quebec. Canadian Journal of Botany 72: 493-498. doi: 10.1139/b94-066.

Ion S (2011) Propagation of some ornamental species (Ligustrum ovalifolium Hassk., Spiraea salicifolia L., Forsythia sp.) at the botanical garden"Al. Buia" from Craiova. Annals of the University of Craiova-Agriculture, Montanology, Cadastre Series 41: 237-242.

IUCN (1998) The IUCN red list of threatened species, Conifer Specialist Group Ver. 2.3.

Jalas J \& Suominen J (1988) Atlas Florae Europaea. Vol. 1. Cambridge University Press, Cambridge, UK.

Jo HJ (2012) Antitumor efficacy evaluation for cedrol dosage form studies. Department of life science and biotechology (Master's thesis), Graduate school, Dong-Eui University.

Keskin S (1992) Kokulu ardıç (Juniperus foetidissima Willd.) ve boylu ardıç (Juniperus excelsa Bieb.)'ın çelikle üretilmesi. Ormancılık Araştırma Enstitüsü Yayınları, Teknik Bülten Serisi No: 233, Ankara, Türkiye.
Leporatti ML \& Ivancheva S (2003) Preliminary comparative analysis of medicinal plants used in the traditional medicine of Bulgaria and Italy. Journal of Ethnopharmacol 87: 123-142. doi: 10.1016/ s0378-8741(03)00047-3.

Lesjak MM, Beara IN, Orčić DZ, Ristić JD, Anačkov GT, Božin BN \& Mimica-Dukić NM (2013) Chemical characterization and biological effects of Juniperus foetidissima Willd. LWT-Food Science and Technology 53: 530-539. doi: 10.1016/j. lwt.2013.03.010.

Lim TK (2012) Edible medicinal and non-medicinal plants. In Fruits 1 Springer, Dordrecht.

Macdonald B (1987) Practical woody plant propagation for nursery growers. Timber Press, Portland, OR, USA.

Moore G (1987) Perlite: Start to finish. Combined Proceedings - International Plant Propagators Society 37: 48-52.

Mukhtar RB (2019) Effect of rooting media and hormone concentrations on vegetative propagation of Balanites aegyptiaca. Journal of Forestry Research 30: 73-76. doi: 10.1007/s11676-018-0622-9.

Negash L (2002) Successful vegetative propagation techniques for the threatened African pencil cedar (Juniperus procera Hoechst. ex Endl.). Forest Ecology and Management 161: 53-64. doi: 0.1016/ S0378-1127(01)00501-1.

Orhan N, Orhan IE \& Ergun F (2011) Insights into cholinesterase inhibitory and antioxidant activities of five Juniperus species. Food and Chemical Toxicology 49: 2305-2312. doi: 10.1016/j. fct.2011.06.031.

Paradikovic N, Zeljkovic S, Tkalec M, Vinkovic T, Dervic I \& Maric M (2013) Influence of rooting powder on propagation of sage (Salvia officinalis L.) and rosemary (Rosmarinus Officinalis L.) with green cuttings. Poljoprivreda (Osijek) 19: 10-15.

Polunin O \& Walters M (1985) A guide to the vegetation of Britain and Europe. Oxford University Press, Oxford, UK.

Randhawa GS \& Mukhapadhaya A (2000) Ornamental and Flowering shrubs. Floriculture in India. Allied Publishers Ltd., New Delhi, India.

Rizi S, Naderi R, Khalighi A, Zamani Z \& Saee A (2006) Effect of plant growth regulators and time of taking cuttings on rooting of three ornamental spruce species. Iranian Journal of Agricultural Sciences (Journal of Agriculture) 37: 719-725.

Song JH, Jang KH \& Hur SD (2010) Propagation of cutting method of a rare endemic Juniperus chinensis var. sargentii Henry in Korea. Korean Journal of Plant Resources 23: 368-373.

Taviano MF, Marino A, Trovato A, Bellinghieri V, La Barbera TM, Güvenç A, Hürkul MM, Pasquale RD \& Miceli N (2011) Antioxidant and antimicrobial activities of branches extracts of five Juniperus spe- 
cies from Turkey. Pharmaceutical Biology 49: 1014 1022. doi: 10.3109/13880209.2011.560161.

Tektas I, Türkoğlu N \& Çavuşoğlu S (2017) Effects of auxin doses on rooting of Juniperus L. Progress in Nutrition 19: 130-136. doi: 10.23751/pn. v19i1-S.5786.

Tümen İ \& Hafızoğlu H (2003) Terpene groups in essential oils of Juniperus L. cones and leaves of grown in Turkey. Journal of Bartin Faculty of Forestry 5: 88-95.

Vakouftsis G, Syros T, Kostas S, Economou AS, Tsoulpha P, Scaltsoyiannes A \& Metaxas D (2009) Effect of IBA, time of cutting collection, type of cuttings and rooting substrate on vegetative propagation in Cupressus macrocarpa 'Goldcrest'. Propagation of Ornamental Plants 9: 65-70.

Yaglioglu AS \& Eser F (2017) Screening of some Juniperus extracts for the phenolic compounds and their antiproliferative activities. South African Journal of Botany 113: 29-33. doi: 10.1016/j. sajb.2017.07.005.

Yıldırım N, Bayraktar A, Atar F, Güney D, Öztürk M \& Turna İ (2020) Effects of different genders and hormones on stem cuttings of Salix anatolica. Journal of Sustainable Forestry 39: 300-308. doi: 10.1080/10549811.2019.1638274. 